\title{
Intrahypothalamic Perfusion of KP102 Stimulates Growth Hormone Release in Goats
}

\author{
Tsutomu HASHIZUME, KoIchi SASAKI, SATOKo KOBAYASHI, AND Yumi NITTA \\ Laboratory of Animal Breeding and Reproduction, Faculty of Agriculture, Iwate University, Morioka 020-8550, Japan
}

\begin{abstract}
The hypothalamic actions of KP102 (also called GHRP-2) on the release of GH were studied in female goats. KP102 (10-5 M) was perfused into the goat hypothalamus through a microdialysis probe (CMA/10 probe with a $4 \mathrm{~mm}$ membrane length) at a rate of $4 \mu \mathrm{l} / \mathrm{min}$ for $90 \mathrm{~min}$, and plasma GH concentrations before and after perfusion were measured. The intrahypothalamic perfusion of $10^{-5} \mathrm{M}$ KP102 significantly stimulated GH release in goats $(P<0.05)$. The GH levels began to rise after commencement of perfusion, and reached a maximum mean value at $180 \mathrm{~min}$. The concentrations of $\mathrm{GH}$ at 165, 180, 195, 210, 225 and 240 min after commencement of perfusion of KP102 were significantly higher than the corresponding values for control animals $(P<0.05)$. KP102 had no effect on GH pulse frequency, but it significantly increased the $\mathrm{GH}$ pulse amplitude after the perfusion $(P<0.05)$. In contrast to KP102, intrahypothalamic perfusion of $10^{-5} \mathrm{M} \mathrm{GHRH}$ had no effect on the stimulation of GH release in goats even if intravenous injection of $10^{-5} \mathrm{M}$ GHRH significantly stimulated $\mathrm{GH}$ release $(P<0.05)$. These results suggest that KP102 may act partly on the hypothalamus to stimulate GH release in goats.
\end{abstract}

Key words: KP102, GHRP-2, GH, Goat, Hypothalamus

(Endocrine Journal 45: 53-59, 1998)

KP102 (also called GHRP-2), a new second generation GH-releasing peptide (GHRP), has potent $\mathrm{GH}$-releasing activity in vitro $[1,2]$ and in vivo [2-8] in several animal species [1, 2, 5-8] as well as humans $[3,4]$. The GH-releasing activity of KP102 has been reported to be more potent than GHRP-6 and GHRP-1 [1, 3], and at present KP102 seems to be the most potent member of the family of GHRPs. The actions and mechanisms of KP102 on the release of $\mathrm{GH}$ are being clarified [1-8]. $\mathrm{KP} 102$ stimulates $\mathrm{GH}$ release by directly acting on the pituitary cells $[1,2]$, but a central action of KP102 has also been suggested $[3,9,10]$ by the following evidence: (1) the family of GHRPs is

\section{Received: May 28, 1997}

Accepted: October 1, 1997

Correspondence to: Dr. Tsutomu HASHIZUME, Laboratory of Animal Breeding and Reproduction, Faculty of Agriculture, Iwate University, Ueda 3, Morioka 0208550, Japan considered to have both direct and indirect actions on the pituitary to stimulate GH release $[3,9,10]$, (2) synergistic or additive $\mathrm{GH}$ release is observed when GH-releasing hormone (GHRH) and KP102 are administered together in vivo $[2,4,5],(3) \mathrm{GH}$ secretagogue-receptor mRNA has been identified in the hypothalamus [11], but the precise in vivo mechanism of GH release by KP102 remains to be clarified. Recently Nakagawa et al. [7] reported that injection of KP102 into the arcuate nucleus or intra-third cerebral ventricle stimulated $\mathrm{GH}$ release in pentobarbital-anesthetized rats. This result was consistent with that of Fairhall et al. [12] who showed that intracerebroventricular (i.c.v.) injection of GHRP-6 stimulated GH release in urethaneanesthetized guinea pigs, but i.c.v. injection of GHRP-6 suppressed GH release in freely moving conscious rats [13]. Since anesthesia modifies GH release [14-16], further precise in vivo experiments on conscious animals are necessary. We have examined the GH-releasing action of KP102 in ruminant animals $[2,8]$. In the present study, 
considering these controversial results, the hypothalamic site of action of KP102 on the release of $\mathrm{GH}$ was examined in conscious goats by a microdialysis technique [17-20]. The action of KP102 was compared with that of GHRH.

\section{Materials and Methods}

\section{Animals}

Seven female Saanen goats in the luteal phase (age, 2-3 years; mean body weight, $45 \mathrm{~kg}$ ) were used. The goat was loosely tied to a stanchion, and natural light was allowed to enter through the windows. The goats were fed hay and concentrate from $0830 \mathrm{~h}$ to $0930 \mathrm{~h}$ and from $1630 \mathrm{~h}$ to $1730 \mathrm{~h}$ daily. Water was available continuously. On the day of the experiment day they were not fed either before or during the experiment, but only after the experiment.

\section{Preparation of KP102 and hGRF(1-29)- $\mathrm{NH}_{2}$}

The KP102 preparation was generously supplied by Kaken Pharmaceutical Co. Ltd., Urayasu, Japan. The hGRF(1-29)- $\mathrm{NH}_{2}$ (GHRH) was supplied by Dr. S. Ohashi, National Institute of Bioscience and Human Technology, Japan. These preparations were dissolved in sterilized artificial cerebrospinal fluid (artificial CSF) [20] before use, and perfused into the goat hypothalamus at a concentration of $10^{-5} \mathrm{M}$ through a microdialysis probe. A concentration of $10^{-5} \mathrm{M}$ was chosen because the GH releasing activity of $10^{-5} \mathrm{M} \mathrm{KP} 102$ had already been confirmed by our preliminary study in the goat. $10^{-5} \mathrm{M}$ GHRH was also prepared by $2 \mathrm{ml}$ of sterilized saline for an experiment on intravenous injection (i.v.) of GHRH.

\section{Intrahypothalamic perfusion system and experiments}

The microdialysis system was previously described by Hashizume et al. [17, 20]. Briefly, unilateral guide tubes were stereotactically implanted into the hypothalamus in each goat at least 2 weeks before the first experiment. On the day of the experiment, the microdialysis probe (CMA/10 probe with a $4 \mathrm{~mm}$ membrane length;
Carnegie Medicine, Stockholm, Sweden) was inserted into the implanted guide tube. Artificial CSF was pumped through the probe tip at a rate of $4 \mu \mathrm{l} / \mathrm{min}$ with a battery-driven syringe pump which was strapped to the goat's back. After the artificial CSF was perfused for $4 \mathrm{~h}$, the CSF was replaced with a solution including $10^{-5} \mathrm{M} \mathrm{KP102}$ or GHRH for $1.5 \mathrm{~h}$, and then the artificial CSF was perfused again for $4 \mathrm{~h}$. Perfusate fractions were discarded, and the microdialysis system was used only as a local delivery technique. In the controls, the artificial CSF was not replaced with a solution including KP102 or GHRH, and only artificial CSF was perfused throughout the experiments. The experiment was performed at the same site in the hypothalamus at 4- or 5-day intervals in each goat. KP102 was perfused in 7 goats, and GHRH was perfused in 4 of 7 goats. At the end of all perfusion experiments, 5 of 7 goats were given a single i.v. injection of $10^{-5} \mathrm{M}$ GHRH or $2 \mathrm{ml}$ of saline (as a control). The injection was given $4 \mathrm{~h}$ after commencement of blood collection, and the blood was collected $4 \mathrm{~h}$ after the injection. The experiments were carried out from September to November.

At the end of the experiments, each goat was anesthetized with intravenous pentobarbital sodium, and the placement of the probe in the brain was histologically confirmed [20].

\section{Blood sampling method}

The jugular venous blood of the experimental animals was taken from the indwelling catheter previously inserted into one of the external jugular veins. Blood samples (one $\mathrm{ml}$ each) were collected into centrifuge tubes containing heparin and were immediately chilled with ice. Blood samples were drawn at 15-min intervals throughout the experiment. Individual plasma samples were obtained after centrifugation and stored at $-20{ }^{\circ} \mathrm{C}$ until assayed.

\section{Radioimmunoassay (RIA)}

Plasma GH concentrations were measured by a double-antibody RIA [21]. The GH standard preparation and hormone for iodination were USDA-bGH-B-1. Antiserum to bGH prepared in monkeys was supplied by Dr. T. Johke (National 
Institute of Animal Industry, Japan) and goatmonkey IgG serum (2nd antibody) was supplied by Dr. K. Wakabayashi (Institute of Endocrinology, Gunma University, Japan). The parallelism between goat plasma GH and bGH was described previously [22]. The intra- and inter-assay coefficients of variation were $5.9 \%$ and $5.8 \%$, respectively. The least detectable value was 0.1 ng/tube.

\section{Statistical analysis}

All data are shown as the mean \pm SEM. GH pulses before, during and after the perfusion of KP102 were identified by the pulse analysis program [23]. The $G$ parameters used for pulse identification in this study were $G(1)=4.4, G(2)=2.6$, $\mathrm{G}(3)=1.92, \mathrm{G}(4)=1.46$ and $\mathrm{G}(5)=1.13$, respectively. These parameters were derived from the values reported by Clarke et al. [24]. The areas under the $\mathrm{GH}$ response curve (AUC) per hour before, during and after the perfusion of KP102 were also calculated. The statistical significance of differences between groups was determined by Student's $t$ test or the Cochran-Cox test after analysis of uniformity of the variances by Bartlett's test [25].
Results were considered significant at the $P<0.05$ level.

\section{Results}

Intrahypothalamic perfusion of $10^{-5} \mathrm{M} \mathrm{KP102}$ stimulated GH release in 7 goats. Representative responses to KP102 in individual animals are shown in Fig. 1. The GH releasing pattern was a little different in each goat. Perfusion of KP102 had no effect on GH pulse frequency, but the GH pulse amplitude tended to increase during perfusion of

Table 1. Characteristics of GH pulses before, during and after intrahypothalamic perfusion of $10^{-5}$ M KP102 in goats

\begin{tabular}{lccc}
\hline & \multicolumn{3}{c}{ Perfusion of KP102 } \\
\cline { 2 - 4 } & Before & During & After \\
\hline Pulse frequency (pulse/h) & $0.7 \pm 0.1$ & $0.8 \pm 0.1$ & $0.8 \pm 0.1$ \\
Pulse amplitude $(\mathrm{ng} / \mathrm{ml})$ & $5.5 \pm 0.6^{\mathrm{b}}$ & $11.4 \pm 3.3^{\mathrm{a}, \mathrm{b}}$ & $13.9 \pm 1.7^{\mathrm{a}}$ \\
\hline
\end{tabular}

Each value represents the mean \pm SEM for 7 animals. ${ }^{a, b}$ Values with different superscript letters indicate significant differences $(P<0.05)$.

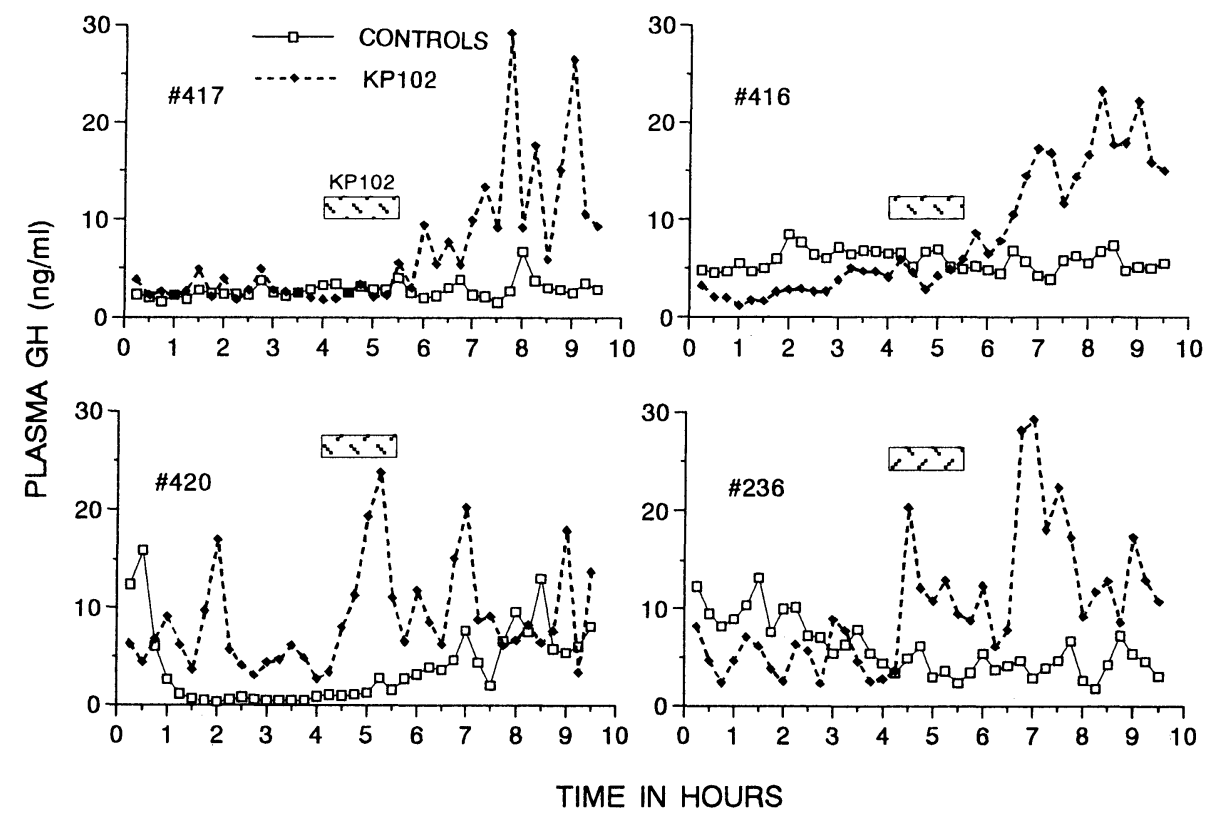

Fig. 1. Typical changes in plasma GH levels before and after intrahypothalamic perfusion of $10^{-5} \mathrm{M} \mathrm{KP102}$ in goats. Four individual results (\#236, \#416, \#417, \#420) obtained from 7 goats are shown. KP102 was perfused through the microdialysis membrane for $90 \mathrm{~min}$. The period of perfusion is indicated by the hatched bar. 


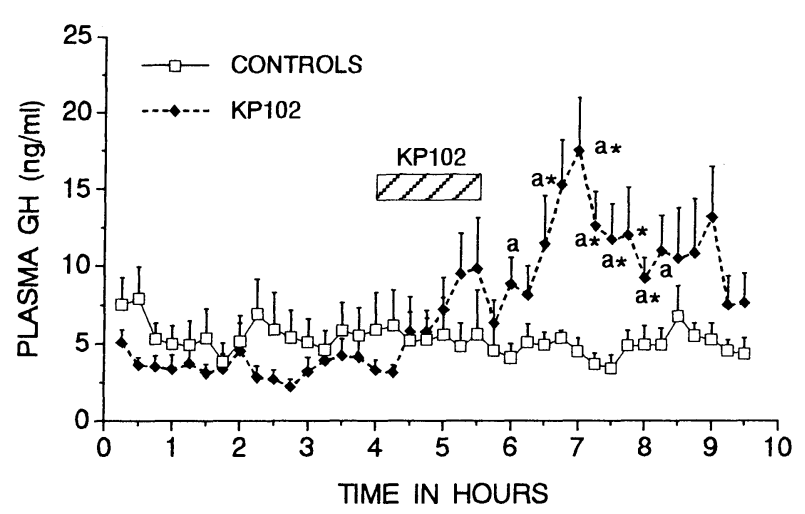

Fig. 2. Average concentrations of plasma GH before and after intrahypothalamic perfusion of $10^{-5} \mathrm{M} \mathrm{KP} 102$ in goats. Each value represents the mean \pm SEM for 7 animals. ${ }^{*} P<0.05$ compared with the corresponding values for controls. a: Significant differences $(P<0.05)$ from pre-KP102 concentrations of $\mathrm{GH}$.

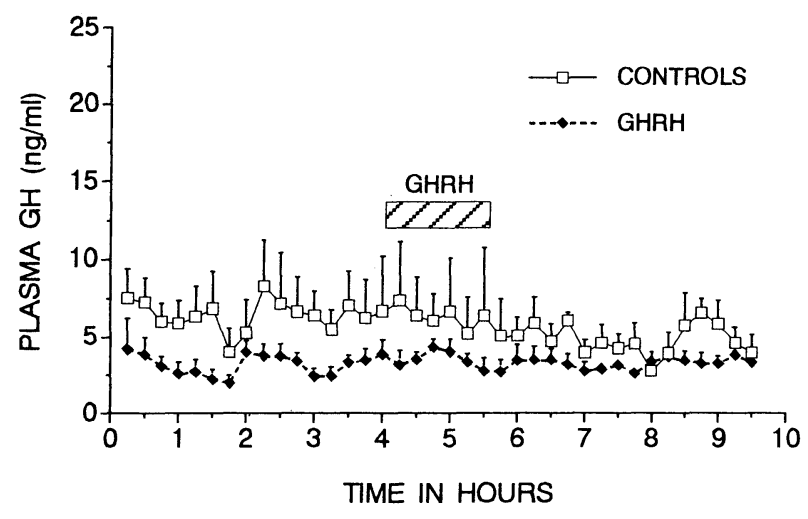

Fig. 3. Average concentrations of plasma GH before and after intrahypothalamic perfusion of $10^{-5} \mathrm{M}$ GHRH (hGRF(1-29) $-\mathrm{NH}_{2}$ ) in goats. Each value represents the mean \pm SEM for 4 animals (\#219, \#236, \#328, \#421). Other explanations are the same as in Fig. 1.

KP102, and it was significantly $(P<0.05)$ increased after the perfusion (Table 1 ).

Figure 2 shows the averaged concentrations of plasma $\mathrm{GH}$ before and after intrahypothalamic perfusion of $10^{-5} \mathrm{M} \mathrm{KP102}$ in 7 goats. The mean plasma GH concentration in control goats varied within the range of 4.3 to $7.9 \mathrm{ng} / \mathrm{ml}$, and no significant changes in the plasma GH levels were observed throughout the experiment. The GH levels began to rise after commencement of perfusion of KP102 from a value of $4.1 \pm 1.1$ (mean $\pm \mathrm{SEM}) \mathrm{ng} / \mathrm{ml}$ at just before perfusion, and reached

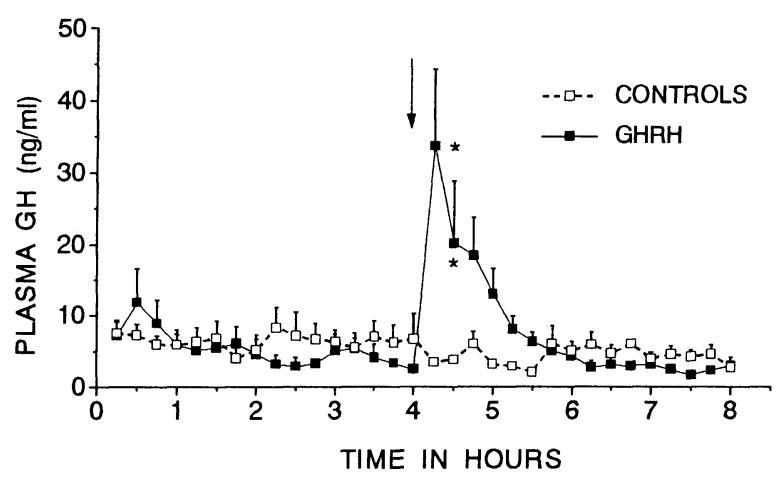

Fig. 4. Plasma $\mathrm{GH}$ responses to the intravenous injection of $10^{-5} \mathrm{M}$ GHRH or saline in goats. Each value represents the mean \pm SEM for 5 animals (\#219, \#236, \#328, \#416, \#421). * $P<0.05$ compared with the corresponding values for controls. An arrow indicates the time of GHRH or saline injection.

a maximum mean value of $17.7 \pm 3.5 \mathrm{ng} / \mathrm{ml}$ after 180 min of perfusion. The concentrations of $\mathrm{GH}$ at $165,180,195,210,225$ and $240 \mathrm{~min}$ after commencement of perfusion of KP102 were significantly $(P<0.05)$ higher than the corresponding values for controls (Fig. 2). The concentrations of GH at 120, 165, 180, 195, 210, 240 and 255 min after commencement of perfusion of KP102 were also significantly $(P<0.05)$ higher than the pre-KP102 concentrations (Fig. 2). The AUC per hour before, during and after the perfusion of KP102 were 246 $\pm 39,379 \pm 79$ and $768 \pm 108 \mathrm{ng} \cdot \mathrm{min} \cdot \mathrm{m} l^{-1}$, respectively, and the AUC after the perfusion was significantly $(P<0.05)$ higher than that either before or during the perfusion.

Figure 3 shows the average concentrations of plasma GH before and after intrahypothalamic perfusion of $10^{-5} \mathrm{M} \mathrm{GHRH}$ in 4 goats. Intrahypothalamic perfusion of $10^{-5} \mathrm{M}$ GHRH had no effect on GH release in goats (Fig. 3), but in contrast to this result, i.v. injection of $10^{-5} \mathrm{M}$ GHRH significantly $(P<0.05)$ stimulated $\mathrm{GH}$ release in the goat (Fig. 4).

Each site of perfusion in the hypothalamus was examined histologically in serial sections of the brain. The areas into which we perfused the test agent in 7 goats were 0 to $4 \mathrm{~mm}$ lateral to the midline of the third ventricle, from 1 to $5 \mathrm{~mm}$ above the base of the hypothalamus. These areas included the preoptic area $(\# 417, \# 421)$, the anterior hypothalamic area (\#328), the arcuate nucleus (\#236), the ventromedial nucleus (\#219) and the 
dorso- and ventromedial nucleus (\#416). The inside of the third ventricle was also perfused in a goat (\#420).

\section{Discussion}

In the present study, we demonstrated that KP102 can act at a hypothalamic site to release GH in goats. This was deduced from the following evidence: (1) KP102 administered into the hypothalamus stimulated GH release, (2) Unlike KP102, the administration of GHRH into the hypothalamus failed to stimulate $\mathrm{GH}$ release.

The central actions of various substances in vivo have been examined mainly by i.c.v. injection methods, but with that method the results obtained may not always be accurate because administered substances can leak out into the bloodstream and reach the pituitary to release hormones directly. And the target site of the brain is obscure even if the administered substances released pituitary hormones by acting indirectly on the pituitary gland. The microinjection method may overcome these drawbacks, but the solution in which the substance is dissolved may affect the cell activity even if the volume of the solution is small, and the substances cannot be administered continuously as in the case of the microdialysis technique. Our microdialysis system allowed us to circumvent these drawbacks, and KP102 was allowed to diffuse gradually into the specific sites.

The GH releasing pattern was a little different in each goat. This was considered to be due to the differences between perfused sites in the goats. GH responses to KP102 in goat \#420 and \#236 promptly occurred when compared with other goats. Perfusion sites in \#420 and \#236 were in the third ventricle and the arcuate nucleus, respectively. Therefore, in these goats, there was the possibility that KP102 had easy access to the arcuate nucleus, where GHRH neurons are located. And KP102 may act on the arcuate nucleus to promptly stimulate $\mathrm{GH}$ release.

$\mathrm{GH}$ responses after i.v. injection of KP102 were a little delayed when compared with GHRH, and the high GH levels gradually decreased to the basal concentrations in the previous study in the goat [8]. Furthermore, some irregular GH peaks appeared after a series of i.v. injections of KP102 [8]. In these respects, our present observations after perfusion of KP102 might be similar to those in the i.v. injection study [8], but the GH release responses after perfusion of KP102 were more continuous than those after i.v. injection [8].

Our results indicating a hypothalamic site of action of KP102 were contrary to the report of Yagi et al. [13] who showed that an i.c.v. injection of GHRP-6 suppressed GH secretion in freely moving male rats. This contradiction might be due to differences between the two experiments in the method of administration. GHRP-6 administered in the 3 rd ventricle is diffused into the cerebrospinal fluid, and GHRP-6 might have access to some neurons to increase somatostatin (SS) and reduce GHRH or both, but this contradiction might be due to differences in the animal species used in the experiments.

There are two possible mechanisms by which KP102 could act centrally to stimulate GH release. First, an intrahypothalamic administration of KP102 could stimulate GHRH neurons directly. An i.v. injection of hexarelin, one of a family of GHRPs, caused an increase in GH levels associated with GHRH release into the hypophysial portal blood in sheep [26]. The i.c.v. or i.v. injection of GHRP-6 into rats increased c-fos expression and firing of neurons in the arcuate nucleus [27]. Moreover, the infusion of GHRP-6 increased GHRH pulse frequency in the hypophysial portal blood in sheep [28]. Second, KP102 could inhibit the neuroendocrine SS cells, resulting in a decrease in SS release into the portal blood, but it was reported that an i.v. injection of hexarelin had no effect on SS release into the hypophysial portal blood in sheep [26]. The infusion of GHRP-6 was also reported to have no effect on the SS concentration, pulse frequency or pulse amplitude in the hypophysial portal blood in sheep [28].

Recently, GH secretagogue (GHS: GHRP-6, MK0677, KP102)-receptor (GHS-R) mRNA was identified not only in the pituitary gland but also in the arcuate-ventromedial hypothalamus and infundibular hypothalamus [11]. Expression of GHS-R on neurons near the median eminence supports the proposed role of the GHS-R as a critical component of a neuroendocrine pathway involved in pulsatile GH release. In the present study, KP102 was administered the base of the hypothalamus, sites which were not with in the arcuate nucleus (except one goat), where GHRH neurons are located, but these sites were close to 
the arcuate nucleus and the KP102 administered was considered to be able to reach the nucleus after traversing the hypothalamic tissues. KP102 was therefore supposed to be able to bind the GHS-R and result in an increase in GH release.

In conclusion, our results suggest that KP102 may act partly on the hypothalamus to stimulate $\mathrm{GH}$ release in goats.

\section{Acknowledgments}

The authors wish to thank Dr. T. Johke, National
Institute of Animal Industry; Japan, for providing GH kits, Dr. K. Wakabayashi, the Institute of Endocrinology, Gunma University, Japan for providing goat anti-monkey IgG serum to bGH and monkey serum, and Dr. S. Ohashi, National Institute of Bioscience and Human Technology, Japan, for providing hGRF(1-29)- $\mathrm{NH}_{2}$. The authors also thank the USDA Animal Hormone Program, USA for providing USDA-bGH-B-1 and Kaken Pharmaceutical Co.Ltd., Japan for providing KP102. This work was supported in part by a Grant-inAid for Scientific Research (07660369) from the Ministry of Education, Science and Culture, Japan.

\section{References}

1. Wu D, Chen C, Katoh K, Zhang J, Clarke IJ (1994) The effect of GH-releasing peptide-2 (GHRP-2 or KP102) on GH secretion from primary cultured ovine pituitary cells can be abolished by a specific GH-releasing factor (GRF) receptor antagonist. J Endocrinol 140: R9-R13.

2. Hashizume $T$, Yanagimoto $M$, Kainuma $S$, Nagano R, Moriwaki K, Ohtsuki K, Sasaki K, Masuda H, Hirata T (1997) Effects of new growth hormonereleasing peptide (KP102) on the release of growth hormone in vitro and in vivo in cattle. Anim Sci Technol (Jpn) 68: 450-458.

3. Bowers CY (1993) GH releasing peptides-structure and kinetics. J Pediatr Endocrinol 6: 21-31.

4. Pihoker C, Middleton R, Reynolds GA, Bowers CY, Badger TM (1995) Diagnostic studies with intravenous and intranasal growth hormonereleasing peptide-2 in children of short stature. $J$ Clin Endocrinol Metab 80: 2987-2992.

5. Sawada H (1995) Effect of newly developed analogue of growth hormone releasing peptide [DAla-D- $\beta$ Nal-Ala-Trp-D-Phe-Lys- $\mathrm{NH}_{2}$ (KP-102)] on growth hormone secretion in adult male rats. $J$ Nippon Med Sch 62: 142-149 (In Japanese).

6. Roh S-G, Matsunaga N, Hidaka S, Hidari H (1996) Characteristics of growth hormone secretion responsiveness to growth hormone-releasing peptide-2 (GHRP-2 or KP102) in calves. Endocr J 43: 291-298.

7. Nakagawa T, Ukai K, Ohyama T, Koida M, Okamura H (1996) Effects of the synthesized growth hormone releasing peptide, KP102, on growth hormone release in sodium glutamate monohydratetreated low growth rats. Life Sci 59: 705-712.

8. Hashizume T, Sasaki K, Sakai M, Tauchi S, Masuda $H$ (1997) The effect of new growth hormonereleasing peptide (KP102) on the release of growth hormone (GH) in goats. Anim Sci Technol (Jpn) 68: 247-256.

9. Laron Z (1995) Growth hormone secretagogues. Clinical experience and therapeutic potential. Drugs 50: 595-601.

10. Korbonits M, Grossman AB (1993) Growth hormone-releasing peptide and its analogues. Novel stimuli to growth hormone release. TEM 6: 43-49.

11. Howard AD, Feighner SD, Cully DF, Arena JP, Liberator PA, Rosenblum CI, Hamelin M, Hreniuk DL, Palyha OC, Anderson J, Paress PS, Diaz C, Chou M, Liu KK, Mckee KK, Pong S-S, Chaung L-Y, Elbrecht A, Dashkevicz M, Heavens R, Rigby M, Sirinathsinghji D J S, Dean DC, Melillo DG, Patchett AA, Nargund R, Griffin PR, DeMartino JA, Gupta SK, Schaeffer JM, Smith RG, Van der Ploeg LHT (1996) A receptor in pituitary and hypothalamus that functions in growth hormone release. Science 273: 974-977.

12. Fairhall KM, Mynett A, Robinson ICAF (1995) Central effects of growth hormone-releasing hexapeptide (GHRP-6) on growth hormone release are inhibited by central somatostatin action. I Endocrinol 144: 555-560.

13. Yagi H, Kaji H, Sato M, Okimura Y, Chihara k (1996) Effect of intravenous or intracerebroventricular injections of His-D-Trp-Ala-Trp-D-Phe-Lys- $\mathrm{NH}_{2}$ on $\mathrm{GH}$ release in conscious, freely moving male rats. Neuroendocrinology 63: 198-206.

14. Kasuya E, Hashizume T, Kanematsu $S$ (1995) The effect of pentobarbital sodium on growth hormone release in shiba goats. Anim Sci Technol (Jpn) 66: 854-856.

15. Kasuya E, Hodate K, Matsumoto M, Sakaguchi M, Hashizume T, Kanematsu S (1996) The effects of xylazine on plasma concentrations of growth hormone, insulin-like growth factor-I, glucose and 
insulin in calves. Endocr J 43: 145-149.

16. Kasuya E, Hodate K, Matsumoto M, Sakaguchi M, Hashizume T, Kanematsu S (1996) Effects of Atipamezole, an $\alpha_{2}$-adrenergic antagonist, and somatostatin on xylazine-induced growth hormone release in calves. Endocr J 43: 551-556.

17. Hashizume T, Nitta $Y$, Kasuya K, Kanematsu S (1995) Microdialysis measurement of intracerebral somatostatin in the goat. Domest Anim Endocrinol 12: 363-370.

18. Ungerstedt U (1991) Microdialysis-principles and applications for studies in animals and man. J Intern Med 230: 365-373.

19. Robinson JE (1995) Microdialysis: A novel tool for research in the reproductive system. Biol Reprod 52: 237-245.

20. Hashizume T, Haglof SA, Malven PV (1994) Intracerebral methionine-enkephalin, serum cortisol, and serum $\beta$-endorphin during acute exposure of sheep to physical or isolation stress. J Anim Sci 72: 700-708.

21. Johke T (1978) Effects of TRH on circulating growth hormone, prolactin and triiodothyronine levels in the bovine. Endocrinol Japon 25: 19-26.

22. Hashizume T, Kanematsu S (1991) Effects of cholecystokinin octapeptide on the release of growth hormone in perifused pituitary and hypothalamus of the goat. Anim Sci Technol (Jpn) 62: 343-350.

23. Merriam GE, Wachter KW (1982) Algorithms for the study of episodic hormone secretion. Am J Physiol 243: E310-E318.

24. Clarke IJ, Fletcher TP, Pomares CC, Holmes JHG, Dunshea F, Thomas GB, Tilbrook AJ, Walton PE, Galloway DB (1993) Effect of high-protein feed supplements on concentrations of growth hormone (GH), insulin-like growth factor-I (IGF-I) and IGFbinding protein- 3 in plasma and on the amounts of $\mathrm{GH}$ and messenger RNA for $\mathrm{GH}$ in the pituitary glands of adult rams. J Endocrinol 138: 421-427.

25. Wakabayashi K (1984) Life Science Personal Computer Series 5, Arrangement of Experimental Data (PC-8801, 9801). Baihukan, Tokyo, 44-57, 90133.

26. Guillaume V, Magnan E, Cataldi M, Dutour A, Sauze N, Renard M, Razafindraibe H, Conte-Devolx B, Deghenghi R, Lenaerts V, Oliver C (1994) Growth hormone $(\mathrm{GH})$-releasing hormone secretion is stimulated by a new GH-releasing hexapeptide in sheep. Endocrinology 135: 1073-1076.

27. Dickson SL, Leng G, Dyball REJ, Smith RG (1995) Central actions of peptide and non-peptide growth hormone secretagogues in the rat. Neuroendocrinology 61: 36-43.

28. Fletcher TP, Thomas GB, Clarke IJ (1996) Growth hormone-releasing hormone and somatostatin concentrations in the hypophysial portal blood of conscious sheep during the infusion of growth hormone-releasing peptide-6. Domest Anim Endocrinol 13: 251-258. 